\title{
Using Life Cycle Assessment to achieve a circular economy
}

\section{Document Version}

Final published version

Link to publication record in Manchester Research Explorer

\section{Citation for published version (APA):}

Pena, C., Civit, B., Gallego Schmid, A., Druckman, A., Caldeira- Pires, A., Weidema, B., Mieras, E., Wang, F., Fava, J., Milà i Canals, L., Cordella, M., Arbuckle, P., Valdivia, S., Fallaha, S., \& Motta, W. (2020). Using Life Cycle Assessment to achieve a circular economy. Life Cycle Initiative.

\section{Published in:}

Life Cycle Initiative

\section{Citing this paper}

Please note that where the full-text provided on Manchester Research Explorer is the Author Accepted Manuscript or Proof version this may differ from the final Published version. If citing, it is advised that you check and use the publisher's definitive version.

\section{General rights}

Copyright and moral rights for the publications made accessible in the Research Explorer are retained by the authors and/or other copyright owners and it is a condition of accessing publications that users recognise and abide by the legal requirements associated with these rights.

\section{Takedown policy}

If you believe that this document breaches copyright please refer to the University of Manchester's Takedown Procedures [http://man.ac.uk/04Y6Bo] or contact uml.scholarlycommunications@manchester.ac.uk providing relevant details, so we can investigate your claim.

\section{OPEN ACCESS}


Position Paper of the Life Cycle Initiative, July 2020

Using Life Cycle Assessment to achieve a circular economy

\begin{abstract}
Contributed by: Claudia Peña*, Bárbara Civit²; Alejandro Gallego-Schmid³ ${ }^{3}$,Angela Druckmann ${ }^{4}$, Armando Caldeira- Pires ${ }^{5}$, Bo Weidema ${ }^{6}$, Eric Mieras ${ }^{7}$, Feng Wang ${ }^{8}$, Jim Fava ${ }^{9}$, Llorenç Milà i Canals ${ }^{8}$, Mauro Cordella ${ }^{10}$, Peter Arbuckle ${ }^{11}$, Sonia Valdivia ${ }^{12}$, Sophie Fallaha ${ }^{13}$, Wladmir Motta ${ }^{14}$.
\end{abstract}

${ }^{1}$ ADDERE, Chile; ${ }^{2}$ National Technological University, Argentina; ${ }^{3}$ University of Manchester, UK; ${ }^{4}$ University of Surrey, UK; ${ }^{5}$ University of Brasilia, Brazil; ${ }^{6}$ Aalborg University, Denmark; ${ }^{7} P R e ́$, The Netherlands; ${ }^{8}$ UNEP, France; ${ }^{9}$ Anthesis Group, Costa Rica; ${ }^{10}$ European Commission (JRC), Spain; ${ }^{11}$ USDA; ${ }^{12}$ World Resource Forum, Switzerland; ${ }^{13}$ CIRAIG Polytechnique Montreal, Canada; ${ }^{14}$ CEFET-RJ, Brazil.

\section{Background and purpose of this position paper}

Circular Economy (CE) is a concept originally coined by Pearce \& Turner ${ }^{1}$ as an economy where wastes are recycled into resources, either through a technological feedback mechanism or through a natural ecosystem feedback mechanism, so that the stock of resources is constant or increasing over time. More recent usage stresses that this aim might also be achieved by keeping products, components, and materials at their highest level of utility and value for as long as possible, designing out waste and pollution and regenerating natural systems ${ }^{2}$. CE is gaining increasingly more attention worldwide as a way to advance efficiently towards sustainable consumption and production patterns ${ }^{3}$. The current global interest in CE opens an opportunity to make society's consumption and production patterns more resource efficient and sustainable. However, such growing interest calls for precaution as well, as there is yet no harmonised method to assess whether a specific CE strategy contributes towards sustainable consumption and production. Life Cycle Assessment (LCA) is very well suited to assess the sustainability impacts of CE strategies.

This position paper provides an LCA perspective on the development, adoption, and implementation of $\mathrm{CE}$, while pointing out strengths and challenges in LCA as an assessment technique for CE strategies.

\footnotetext{
1 Pearce D W, Turner P K. (1990). The economics of natural resources and the environment. Hemel Hempstead: Harvester Wheatsheaf

2 EMF. 2012: Ellen MacArthur Foundation Towards the Circular Economy

${ }^{3}$ UNEA4/Res.1 Innovative pathways to achieve sustainable consumption and production
}

\section{Circular Economy and its challenges}

The objective of the CE may be achieved through the application of CE strategies, or value retention loops, for instance as illustrated in UNEP's Building Circularity platform. The transition to CE implies direct linkages to international trade, and may lead to structural changes in the economy, which in turn may impact on trade flows of primary and secondary resources ${ }^{4}$. If emerging economies are left out of the analysis of the consequences of CE design and strategies, it could lead to adverse ecological, social and economic consequences, because they are part of the global supply chain of many production systems. This calls for a holistic assessment of the economic, social, and ecological transition pathways along the value chain.

Recycling is not always the best option...

Levi Strauss conducted and published a life cycle assessment on their iconic 501 denim jeans. The study identified two life cycle areas that are major contributors to environmental impacts: cotton production and washing the jeans. It stands to reason that recycling creates opportunities for eliminating the dependence on virgin cotton. However, a closer look at the recycling systems in place shows that cotton textile recycling results in shorter fibre lengths, which reduces their ability to be used in new products. Recycled fibers must be blended with either virgin cotton or with other materials, such as recycled plastics, to create different types of textiles. Of course, recycled fibers can also be used to create new materials for other applications, such as insulation. Facing uncertainty about the best options for recycling, other solutions such as reuse and other recovery options may have more environmental gains. To assess and compare different strategies for $C E, L C A$ is a very useful technique to consistently and effectively quantify systemic impacts, by answering questions such as: What is the best pathway for improving the circularity of the textile sectors?

[PRé 2016]

${ }^{4}$ OECD. (2018). International Trade and the Transition to a Circular Economy 


\section{(2) Life cycle intitative}

At the same time, decision-making processes in CE strategies could be biased by a naïve understanding of what "closing the loop" implies (see box). CE approaches that focus on specific physical resources may assume that these resources are the most valuable area of protection, ignoring other resources / impacts. Consequently, there is a need to develop assessment techniques that can prevent CE strategies from overlooking potential upstream and downstream impacts as well as shifting the burden of those impacts from one resource or impact area to another, which could lead to inappropriate or less efficient solutions.

\section{Strengths of Life Cycle Assessment to assess Circular} Economy strategies

Life Cycle Assessment is a science-based technique for assessing the impacts associated with entire product life cycles, standardised in the ISO 14040-series. LCA can provide technical support to CE decision-makers, to assess trade-offs of impacts on a variety of environmental impact indicators, such as water use, energy, climate change, and raw materials. LCA may also be applied to identify the most promising $C E$ strategies and options for improving the environmental performance of society's consumption and production patterns. For example, LCA provides a correction to economic analyses based on current taxation regimes, where labour is taxed more than material resources.

LCA can also bring a holistic perspective into decisionmaking, by assessing beyond the biophysical environment into the social and economic effects of a decision (also called a Life Cycle Sustainability Assessment, LCSA). LCA can highlight situations where CE projects may be too narrowly focussed on the "circularity" of a specific resource, and where the specific circular strategy is not the best choice from a broader sustainability perspective.

\section{Challenges of applying LCA to assess Circular Economy strategies}

For a better application of LCA to support CE strategies, a number of shortcomings of the current LCA need to be resolved, notably:
- Consistent accounting for changes in stocks of resources respecting mass balance principles.

- Consistent modelling of open recycling loops.

- The inclusion of all relevant resources and impacts, i.e. a full economy-wide LCSA perspective.

- Transparency of assumptions, reliability of data, and critical interpretation of results and trade-offs between a globally agreed numbers of impact categories, e.g. through valuation, as suggested in ISO 14008.

Position and recommendations of the Life Cycle Initiative

The Life Cycle Initiative promotes using LCA as a methodology to build more robust CE strategies that consider potential upstream and downstream impacts and encompass all relevant resources and impact categories, leading to better decisions for sustainability. The inclusion of the life cycle perspective when assessing CE strategies requires LCA professionals to address the technical and scientific challenges involved in this assessment, as well as the implications for the sustainability of both emerging and developed economies. Specifically, the Life Cycle Initiative aims to contribute to:

- Consensus building within the LCA community on terminology related to $\mathrm{CE}$;

- Resolve the technical and scientific challenges to advance in the implementation of LCA in the assessment of CE strategies;

- Assessment methodology and metrics for CE, starting from the recognition of historical limitations in the way LCA models raw materials and resource considerations (which often take the linear economy as the frame of reference);

- Global and regional CE forums, particularly within the technical working groups of the ISO of CE (TC / 323);

- Promote the application of LCA in assessing and planning CE strategies, i.e. involving the LCA community globally in designing the approach, monitoring and evaluation, as well as in data collection and assessment of CE strategies. 